\begin{tabular}{|c|c|c|}
\hline $\begin{array}{l}\text { KULTURA } \\
\text { I } \\
\text { SPOLECZENS }\end{array}$ & $\begin{array}{l}\text { POLSKA AKADEMIA NAUK } \\
\text { KOMITET SOCJOLOGII } \\
\text { INSTYTUT STUDIÓW POLITYCZNYCH } \\
2015, \mathrm{nr} 4\end{array}$ & ISSN 0023-5172 \\
\hline
\end{tabular}

MAEGORZATA BUDYTA-BUDZYŃSKA

Collegium Civitas

\title{
POSTPOLITYCZNA DEMOKRACJA NIEUFNYCH NA MARGINESIE ESEJÓW IWANA KRASTEWA
}

\begin{abstract}
„Politycy i media ukazują niemal każde wybory jako punkt zwrotny - wybór, który zdefiniuje los kraju na lata. Kiedy jednak wybory się skończą, świat magicznie wraca do normy".

Iwan Krastew, Demokracja: przepraszamy za usterki
\end{abstract}

Iwan Krastew, bułgarski politolog, w dwóch esejach wydanych ostatnio po polsku przez Krytykę Polityczną: Demokracja nieufnych (2013) i Demokracja: przepraszamy za usterki (2015), zastanawia się nad kondycją współczesnej demokracji oraz nad tym, czy masowe protesty na ulicach wielu miast świata w początkach drugiej dekady XXI wieku były znakiem jej kryzysu, sukcesu, czy może sposobem realizacji demokracji innymi środkami. Eseje Krastewa nie są receptą, jak zaradzić kryzysowi demokracji, ale raczej diagnozą sytuacji. Autor, którego Sławomir Sierakowski we wstępie do Demokracji nieufnych nazywa bałkańskim tropicielem idei, parafrazując błyskotliwe określenia samego Krastewa użyte w stosunku do Seymoura Lipseta, prowokuje do refleksji, stawiając wnikliwe pytania, które jednak najczęściej pozostawia bez odpowiedzi.

Demokracja przez stulecia miała liczne grono krytyków, do którego należeli między innymi Alexis de Tocqueville, Ortega y Gasset i Raymond Aron, by wymienić tylko tych trzech myślicieli z różnych epok i różnych krajów. Jednak dość powszechnie uważano, że - jak to wyraził Winston Churchill — jest to najlepszy z możliwych ustrojów, dlatego trzeba go raczej poprawiać niż wymieniać. Dziś sytuacja jest inna - mówi Krastew - pojawiło się powszechne rozcza- 
rowanie demokracją, jej ideami, instytucjami, a przede wszystkim praktyką. Brak jest wiary, że demokracja służy dobru zbiorowemu i że wybory cokolwiek zmieniają. „W demokracji nie chodzi już o politykę, to pomysł na dobry biznes" - stwierdza autor (2013, s. 15). Dlaczego tryumf demokracji na świecie, mierzony liczbą państw określanych jako demokratyczne, jednocześnie skutkuje poczuciem kryzysu demokracji w miejscach, gdzie powstała i gdzie się rozwijała: w Europie i Stanach Zjednoczonych?

Demokracja bywała w kryzysie, ale wierzono w jej autonaprawę. Pomyślność konkretnej demokracji zależała od zdolności jej elit do autorefleksji i korekty nieudanych polityk. Tak było w latach siedemdziesiątych ubiegłego wieku, kiedy ludzie stracili wiarę $\mathrm{w}$ demokrację, ale zachowali wiarę $\mathrm{w}$ rynek, $\mathrm{i}$ to rynek oraz neoliberalne reformy odroczyły kryzys demokracji i dały poczucie sukcesu. Teraz jest inaczej. I rządy, i rynek nie cieszą się zaufaniem wyborców. Rewolucja rynkowa przełomu lat siedemdziesiątych i osiemdziesiątych, która zapobiegła ówczesnemu kryzysowi demokracji, przyniosła wzrost bogactwa, ale nie dystrybuowano go równo. Doprowadziło to do pojawienia się w demokracji rynkowej wewnętrznej sprzeczności, której nie daje się wyeliminować. Demokracja rynkowa oparta jest na dwóch wykluczających się zasadach: część demokratyczna na zasadzie jeden człowiek = jeden głos, część rynkowa jeden dolar $=$ jeden głos (Krastew 2013; por. rozważania na ten temat Chang 2015, s. 331). Ważniejsza okazała się ta druga zasada, czyli siła rynków finansowych. „Polityka została zredukowana do sztuki dostosowywania się do wymogów rynku" - pisze Krastew (2013, s. 19). I to jest źródło kryzysu, a przede wszystkim niemożności autokorekty demokracji.

W sytuacji dominacji rynków finansowych wybory nie mobilizują biernych i nie pacyfikują oburzonych, mają drugorzędne znaczenie. Współczesna demokracja z cyklami wyborczymi stała się postpolityczna - zmienia rządy, ale nie jest $\mathrm{w}$ stanie zmienić dysfunkcjonalnych polityk, $\mathrm{w}$ tym sensie jest $\mathrm{w}$ kryzysie. Obywatel-żołnierz, obywatel-pracownik, obywatel-konsument stracił znaczenie, bo armia jest zawodowa, produkcję w każdej chwili można przenieść gdzie indziej, a stan gospodarki nie zależy od siły nabywczej lokalnej ludności. Krastew pisze „o świecie bez realnych wyborców”.

Nawet jeśli przyjmie się bardzo pragmatyczną i ograniczoną definicję demokracji Josepha Schumpetera (2009, s. 336-337) — jako wolnej rywalizacji elit, $\mathrm{w}$ której masy uczestniczą $\mathrm{w}$ polityce poprzez sporadycznie organizowane wybory - to dzisiaj i taka demokracja nie działa. Krastew nie odnosi się w swoich esejach explicite do teorii Schumpetera, ale zadaje schumpeterowskie pytanie: czy prawo wyboru polityki jest dziś w ogóle realizowane, skoro ludzie mają poczucie, że głosowanie niczego nie zmienia. Schumpeter uważał, że ludzie mają niewielki wpływ na decyzje polityczne i oczywiście nie rządzą, jak utrzymywali niektórzy klasycy demokracji, wierzył jednak, że mają wpływ na wybór rządzących i tym samym kierunek realizowanej przez nich polityki. Krastew dowodzi, że nawet tak minimalne poczucie demokracji się skończyło. Wybory niczego nie 
zmieniają poza ekipą staro-nowych polityków, gdyż sama polityka się nie zmienia. Obecne poczucie kryzysu dotyczy demokracji rozumianej substancjalnie - jako ustroju pozwalającego wybierać reprezentatywne władze działające dla dobra publicznego. W tym sensie polityka jako sztuka zarządzania sprawami publicznymi ${ }^{1}$ ma coraz mniejsze znaczenie.

Proponuje się trzy sposoby przeciwdziałania powszechnemu odczuciu kryzysu demokracji ${ }^{2}$ : więcej wyborów jako metodę kontroli polityków, więcej referendów, czyli demokrację bezpośrednią jako aktywniejszy sposób partycypacji obywateli w polityce, i większą transparentność decyzji politycznych. Autor Demokracji nieufnych wskazuje na ograniczenia i nieadekwatność do bieżącej sytuacji każdej z tych propozycji.

Wyborów - tego crème de la crème demokracji — jest coraz więcej, ale ich istotność jest coraz mniejsza, nastąpiła „erozja sił demokratycznego głosu” (Krastew 2013, s. 13), co przejawia się w spadku frekwencji wyborczej we wszystkich krajach i buncie białych kartek (oddawanie nieważnego głosu, bez skreśleń). To paradoks wyboru, że im więcej wybieramy, tym mniej cenimy wybory i jesteśmy niezadowoleni z wyborów. Świetnie to widać we współczesnych demokracjach europejskich, gdy w kilka miesięcy po wyborach sondaże pokazują spadek poparcia dla władzy. Gdy wielu oburzonych bierze udział w wyborach, by po kilku miesiącach protestować przeciw wybranym, często nie pamiętając, na kogo głosowali. W tym sensie można powiedzieć, że kryzys demokracji wynika nie z jej klęski, ale jej sukcesu - rozpowszechnienia wyborów, które zastąpiły kompetentne decyzje polityczne.

Drugą receptą na kryzys współczesnej demokracji przedstawicielskiej miałaby być demokracja bezpośrednia, która dopiero teraz, po rewolucji informatycznej, stała się w pełni możliwa na dużych terytoriach, tym samym zakwestionowała zasadność instytucji przedstawicielskich. Demokracja przedstawicielska jest obecnie postrzegana jako etap przejściowy między dwiema pełnymi demokracjami: bezpośrednią demokracją greckiego polis w przeszłości i bezpośrednią demokracją cyfrową przyszłości. Ale czy rzeczywiście „klikająca” demokracja może rozwiązać złożone problemy współczesnych państw? Demokracja pośrednia była formą demokracji przyjętą nie tylko ze względu na trudności związane $z$ rozmiarami państwa, ale przede wszystkim z powodu mnogości spraw i ich skomplikowania. Teraz tych spraw jest jeszcze więcej i są nieporównanie bardziej złożone. W czasach rewolucji cyfrowej możemy wprawdzie

\footnotetext{
${ }^{1}$ Jedna z czterech definicji polityki w podręczniku Politologia Andrew Heywooda (2010, s. 10).

2 Można pytać, skąd tak powszechne przekonanie o kryzysie zaufania. Niektórzy odpowiadają, że z powodu zmiany struktury społecznej - wzrostu liczby ludzi wykształconych i uświadomionych politycznie. Inni, że z powodu zmiany stylu uprawiania polityki, który kiedyś obfitował w debaty i prawdziwe kampanie polityczne, dziś zostały one zastapione marketingiem politycznym. Nieufność może też wynikać z niesymetrycznych relacji - korzystania z pewnych instytucji, których nie lubimy i nie cenimy, ale nie możemy z nich zrezygnować, jesteśmy zmuszeni do korzystania z nich.
} 
uzyskać więcej informacji, ale ze względu na ich segregację i fragmentaryzację obraz świata nie musi być bardziej zrozumiały, przeciwnie może być węższy niż przed usieciowieniem. Ilość informacji nie przekłada się bezpośrednio na jakość analiz, a tym bardziej decyzji politycznych. Poza tym wielka liczba kontaktów możliwych w sieci wcale nie implikuje wspólnych celów i zbiorowego działania.

Trzecią z dyskutowanych przez Krastewa propozycji rozwiązania kryzysu demokracji jest większa transparentność decyzji politycznych, i tu krytyka Krastewa jest najmocniejsza i najciekawsza ${ }^{3}$. Transparentność decyzji politycznych w ustach niektórych działaczy społecznych urasta do rangi nowej religii stwierdza z ironią Krastew - wierzą oni naiwnie, że „przejrzystość” polityki uzdrowi i odbuduje obywatelskie zaufanie do demokracji i państwa, a w rzeczywistości może być odwrotnie. „Wbrew deklarowanej ambicji odbudowania zaufania do instytucji demokratycznych ruch na rzecz transparentności może przyspieszyć przekształcanie się demokratycznej polityki w zarządzanie nieufnością” (2013, s. 52). Dlaczego? Przede wszystkim dlatego, że: „Zmierzch tajemnicy państwowej nie oznacza poinformowanego obywatela, tak samo jak większa kontrola nie oznacza większego zaufania do instytucji publicznych. [...] a zalewanie ludzi informacjami jest od dawna sprawdzoną metodą na utrzymanie ich w stanie niewiedzy" (2013, s. 51). Przesadna jawność może demokracji nie pomóc, a nawet jej szkodzić, na co wskazują przykłady rosyjski i bułgarski, gdy monitorowanie wyborów i posiedzeń rządu nie tylko nie zwiększyło zaufania do polityków, ale było instrumentem w rękach rządzących służącym do spacyfikowania krytycznych nastrojów w społeczeństwie i elicie władzy. Po drugie - mówi autor Demokracji nieufnych - istnieje wyraźna sprzeczność między oczekiwaniem całkowitej przejrzystości władzy i jednoczesnej ochrony prywatności obywatela. Te dwa wymagania jednocześnie nie są możliwe do spełnienia. Żądanie pełnej jawności polityki to, zdaniem Krastewa, odwrócony benthamowski Panoptikon: „Totalitarną antyutopię ludzi szpiegujących dla rządu zastępuje postępowa utopia o ludziach szpiegujących rząd" (2013, s. 53). Po trzecie w końcu, skupienie się na przejrzystości w reformie demokracji nie jest alternatywą dla demokracji nieufności, bo przejrzysty proces decyzyjny nie równa się dobrej polityce, to tylko (i aż) forma jej uprawiania. „To, w jaki sposób podejmuje się decyzje, nie zastąpi fundamentalnego pytania, co jest najlepsze dla społeczeństwa" (2013, s. 60). Krastew jest radykalnym przeciwnikiem polityki pełnej jawności jako metody poprawiania demokracji!

Tyle Krastew i jego diagnoza, z którą trudno się nie zgodzić. Przeświadczenie, że demokracja w obecnym kształcie doszła już do ściany, jest dość powszechne - stąd wiele dyskusji dotyczących jej modyfikacji. Ale czy należy ratować ten model demokracji, czy demokrację wymyślić na nowo?

${ }^{3}$ Argumenty zawarte w książce Krastew powtórzył na Uniwersytecie Warszawskim podczas debaty Tischnerowskiej „Demokracja, internet, przyszłość”, 12 marca 2015 r. 
Demokracja na przestrzeni stuleci zmieniała się, co nie znaczy ewoluowała, była raczej wymyślana na nowo. Charles Tilly w książce Demokracja (2008, s. 39$-68,235)$ dowodzi, że współczesna demokracja nie powstała w wyniku ewolucji demokracji ateńskiej, weneckiej czy florenckiej, ale jest systemem, który ukształtował się bez związku ze swoimi słynnymi poprzedniczkami. Podobnie uważa Giovanni Sartoti, który w Teorii demokracji (1998, s. 341-358) przekonuje, że doświadczenia ateńskie są kompletnie nieprzydatne dla nowoczesnej polityki. Różnice dotyczą nie tylko rozmiaru państwa i jego etnicznego składu oraz rodzaju demokracji: bezpośrednia versus przedstawicielska, ale również sposobu wyboru reprezentantów. W Wenecji byli wybierani losowo, w osiemnastowiecznej Ameryce z osób niezrzeszonych, w XX wieku z grona członków partii politycznych. Być może obecnie dochodzimy do kolejnego etapu - przejścia od rywalizacji wyborczej zdominowanej przez partie do wyborów innego typu, na przykład osób ze stowarzyszeń i organizacji innych niż partie.

Obmyślając, w pewnym sensie, demokrację na nowo, trzeba odpowiedzieć na kilka fundamentalnych pytań. Pierwsze dotyczy określenia wspólnoty politycznej, w której ma być praktykowana demokracja. Kto miałby do niej należeć? Tylko obywatele, nieważne, czy mieszkający w kraju czy poza nim? Czy ci, którzy zamieszkują państwo, więc również tacy, którzy obywatelstwa dziś nie posiadają? Jeśli przyjmiemy to pierwsze rozwiązanie, to emigranci zachowujący obywatelstwo kraju ojczystego powinni nie tylko mieć czynne prawo wyborcze, ale również bierne, dzięki czemu mieliby swoje przedstawicielstwo we władzach ustawodawczych i wykonawczych. Oznaczałoby to rzeczywiste uczestnictwo diaspory $\mathrm{w}$ procesie podejmowania decyzji politycznych. Taka propozycja rodzi jednak pytania: jak miałyby wyglądać wybory osób z diaspory? Czy nie dochodziłoby do permanentnego zdominowania przedstawicielstwa diaspory przez osoby z jednego kraju, w którym - ze względu na istnienie tradycyjnych łańcuchów emigracyjnych lub dobrą koniunkturę gospodarczą - liczba emigrantów jest największa? Czy na czas zasiadania w ojczystym parlamencie osoby takie miałyby wrócić z emigracji? Problem wydaje się wydumany, ale propozycje dotyczące ściślejszych kontaktów z diasporami są dyskutowane, również w Polsce (projekt konstytucji PiS z 2010 roku). Istnieją państwa, na przykład Włochy, które mają reprezentacje swoich diaspor w ciałach przedstawicielskich ${ }^{4}$.

Jeśli miałoby być przyjęte drugie rozwiązanie, to partycypacja polityczna wynikałaby z zasady rezydencji - ius domicilii. Jest ona powszechnie stosowana w UE i w niektórych państwach strefy Schengen na poziomie wyborów

\footnotetext{
${ }^{4}$ Czynne prawo wyborcze dla emigrantów też nie jest oczywiste. Po wyborach parlamentarnych w Polsce w października 2015 roku rozgorzała dyskusja w internecie, czy emigranci — nie mieszkający w kraju i niepłacący tu podatków - powinni mieć prawo decydowania o tym, co się w nim dzieje. „Nie mieszkasz, nie decydujesz” — przekonywali zwolennicy odebrania praw wyborczych emigrantom.
} 
municypalnych - osoby mające status rezydenta, najczęściej po pięciu latach legalnego przebywania i pracy w kraju przyjmującym, mogą brać udział w sposób czynny i bierny - w wyborach lokalnych ${ }^{5}$. Obecnie chodziłoby o to, by rozszerzyć tę zasadę na imigrantów spoza Unii i na wybory parlamentarne. Poszerzanie praw imigranckich obywałoby się zatem $\mathrm{w}$ odwrotnej kolejności niż wprowadzanie praw obywatelskich, jak to opisał Marshall (1950), a więc imigranci otrzymaliby pełne prawa polityczne po tym, jak korzystają już z praw socjalnych.

Zwolennicy tego rozwiązania dowodzą, że inkluzja polityczna imigrantów wpłynie korzystnie na ich szybszą i skuteczniejszą integrację ze społeczeństwem przyjmującym, bo potwierdzi ich stan przynależności i upodmiotowi imigrantów (stosowane w tej argumentacji pojęcie agency). Poza tym płacą oni podatki i powinni mieć prawo decydowania (amerykańska zasada z czasów walki o niepodległość no taxation without representation). Przeciwnicy przekonują, że nie ma wystarczających dowodów na to, że prawa wyborcze, czyli inkluzja formalnoprawna przyspiesza proces integracji, bo nie likwiduje ona innych barier, których źródłem nie jest prawo (Lesińska 2013). Przykład społeczności z Maghrebu we Francji, tzw. beurs, pokazuje, że posiadanie obywatelstwa niekoniecznie skutkuje poczuciem więzi z krajem zamieszkania. Trzeba też pamiętać, że włączenie emigrantów do wspólnoty politycznej to również włączenie ich kultury do kultury ogólnopaństwowej, to jej obecność w przestrzeni publicznej (problem meczetów, również w Polsce problem z meczetem na warszawskiej Ochocie otwartym w lipcu 2015 roku). To także dotacje z państwowego budżetu na potrzeby kulturalne (i religijne, jeśli religia jest finansowana przez państwo) członków tej społeczności i zgoda na ich obecność we władzach ustawodawczych, na przykład w Izbie Lordów obok biskupa zasiadałby mułła (Modood 2014, s. 73-93).

Drugie pytanie dotyczy ograniczeń konstytucyjnych demokracji większości, czyli praw, jakie miałyby mieć mniejszości. U podstaw demokracji liberalnej leżało przeświadczenie o równym traktowaniu wszystkich obywateli, niezależnie od ich pochodzenia i statusu społecznego. Jednak przez niedostrzeganie „różnic” między zbiorowościami tworzącymi społeczeństwo skrywano wykluczenie niektórych z nich. Jednym z rozwiązań wyrównujących szanse marginalizowanych grup jest ustalanie kwot w składzie ciał przedstawicielskich, miejscach na państwowych uczelniach i miejscach pracy w instytucjach państwowych w imię zasady, by te instytucje odzwierciedlały zróżnicowanie społeczeństwa. Innym rozwiązaniem jest demokracja konstytucyjna zabezpieczająca mniejszości przed decyzjami większości naruszającymi ich prawa zawarte w konstytucji lub w innych aktach prawnych. Jeszcze inną propozycją jest tzw. polityka róż-

\footnotetext{
${ }^{5}$ Konwencja RE z 1992 roku nt. partycypacji cudzoziemców w życiu publicznym na poziomie lokalnym, weszła w życie w 1997 roku. Obywatele Unii mogą uczestniczyć w wyborach lokalnych na mocy dyrektywy unijnej nr 94/80.
} 
nicy polegająca na przyznawaniu dodatkowych praw grupom upośledzonym. W końcówce XX wieku Will Kymlicka, „prorok” multikulturalizmu, i filozof Charles Taylor przekonywali do odejścia od polityki ślepoty na różnice (colou-blindness) na rzecz polityki „wspierania różnicy” (Kymlicka 1989, 1995; Taylor 1992). Taka polityka wydaje się antywiększościowa, ale uwiarygodnia demokrację, bo tylko przy takich dodatkowych prawach można mówić o rzeczywistej równości ${ }^{6}$. Postulat Kymlicki i Taylora dotyczył jednak mniejszości rdzennych, autochtonicznych (mniejszości etnicznych i narodowych), w czym zresztą przejawiało się doświadczenie kanadyjskie obu autorów. Obecny problem dotyczy praw do „różnicy”: których grup prawa te miałyby dotyczyć? Postuluje się, by podejście poszanowania „różnicy” stosować również w stosunku do emigrantów i mniejszości religijnych, które — jak w przypadku mniejszości islamskiej - trudno odróżnić od etnicznych. Nastąpiłoby zatem przesunięcie polityki poszanowania „różnicy” z grup terytorialnych (mniejszości narodowych) na grupy tożsamościowe (imigrantów, inne mniejszości).

Kolejny problem to autonomia w ramach demokracji. Czy i do jakiego stopnia różne społeczności terytorialne powinny mieć autonomię $\mathrm{w}$ ramach demokracji? Jeśli wprowadzać autonomię pewnych regionów, to takie jednostki terytorialne miałyby wpływ na decyzje polityczne niejako podwójnie - w ramach swojej autonomii i w ramach całości, co może przeczyć zasadzie równości (taki argument pojawił się w 1939 roku, gdy Chorwacja otrzymała autonomię, tzw. Banowinę Chorwacką w ramach Królestwa Jugosławii). Jeśli zachować zasadę równości, to każda część państwa otrzymałaby autonomię, czyli byłaby to zwykła decentralizacja.

Czwarte pytanie dotyczy relacji między sferą publiczną i prywatną oraz stosunków między formalnymi i nieformalnymi trybami działalności politycznej. Dzisiaj w wielu przypadkach jest ona zatarta, nieczytelna, nie ma transparentności w tym zakresie. Obszary te należałoby na nowo zdefiniować i wytyczyć między nimi granice.

I ostatnie pytanie związane jest z różnymi formami partycypacji politycznej $\mathrm{w}$ procesie podejmowania decyzji. Ile w demokracji przedstawicielskiej miałoby być demokracji bezpośredniej? Chodziłoby zatem o znalezienie takich sposobów bezpośredniego uczestnictwa obywateli w polityce, które jednocześnie nie wymagałyby porzucania zasady reprezentacji, bo nie jest prawdą, że z pomocą współczesnych narzędzi informatycznych reprezentację można wyeliminować. Prekursorzy współczesnej demokracji ostrzegali, że demokracja bezpośrednia nie jest możliwa. Monteskiusz w O duchu praw (1997, s. 12) pisał: „Ludzie są zdolni wybierać, ale nie rządzić”, James Madison w Federalist Papers (63 para-

\footnotetext{
${ }^{6}$ Iris Young (2000) rozróżniła dwa rodzaje równości: równość wynikającą ze stosowania tych samych zasad i równość wynikającą z zestawu zasad i norm, które nie sprawiają, że w wyniku ich stosowania strony stają się bardziej lub mniej uprzywilejowane, dlatego że uczucia i potrzeby wszystkich stron zostały wzięte pod uwagę.
} 
graf 14) zalecał „zupełne wykluczenie osób w swojej zdolności zbiorowej do udziału w rządzeniu". Demokracja przedstawicielska jest nie do zastąpienia, ale bezpośrednia daje poczucie rzeczywistego wpływania na proces decyzyjny, chodzi o to, by cechy obu połączyć w jakieś rozsądnej proporcji.

Niektórzy uważają, że realizacją takiego wymagania jest demokracja szwajcarska, którą Helweci próbują zresztą eksportować 7 . Obywatele traktowani są tam jak trzecia izba władz ustawodawczych - ustawy przyjmowane przez obie izby parlamentu dodatkowo poddawane są głosowaniu w referendach (obligatoryjnych lub opcjonalnych). Partie polityczne wystawiają kandydatów do parlamentu i na wybieralne urzędy, czyli spełniony jest wymóg demokracji przedstawicielskiej, ale dalej muszą oni walczyć o wynik w referendum. Propozycja staje się prawem, gdy wedle ustalonego kryterium (większości bezwzględnej, zwykłej większości czy podwójnej większości) przejdzie w referendum kantonalnym. W tego typu demokracji władza niewiele się zmienia, bo chcąc uzyskać pozytywny wynik w referendum (gdy jest obowiązkowe) lub go uniknąć (gdy jest opcjonalne), tworzy się szeroką koalicję rządzącą, która niemal wszystko negocjuje. Proponująca zmiany większość w parlamencie nie wie, czy opozycja zażąda referendum, co może opóźnić wprowadzanie reform albo całkowicie je zablokować, dlatego obawiając się referendum tak długo prowadzi negocjacje, aż osiągnie kompromis. Referendum jest czynnikiem zmuszającym do zgody. Demokracja referendalna w sposób niezamierzony staje się demokracją koncyliacyjną. Mocną stroną tego typu demokracji jest silna legitymizacja $\mathrm{w}$ postaci władzy suwerena, kontroli elit, zaangażowania obywateli w proces polityczny i przede wszystkim obywatelska edukacja, na której ważność zwracał uwagę już John Stuart Mill w O rzadzie reprezentatywnym. Negatywna strona demokracji bezpośredniej dotyczy jakości wyborów dokonywanych przez obywateli. Nierzadko są oni słabo poinformowani i niekompetentni, by podejmować odpowiedzialne decyzje. W sprawach bardziej skomplikowanych głosują na ogół lepiej zorientowani, czyli demokracja bezpośrednia staje się demokracją warstw średnich, przy trudnych projektach istnieje duże prawdopodobieństwo wykluczenia całych rzesz ludności z systemu współdecydowania. Ponadto w przypadku złożonych kwestii za pomocą propagandy można wpływać na wynik. Demokracja referendalna jest podatna na manipulacje ze strony demagogów i populistów, bo decyduje w niej większość, a to znaczy przeciętność. Inne negatywne cechy demokracji bezpośredniej to opinia, że jest powolna i bardziej ociężała niż demokracja przedstawicielska, proces decyzyjny jest długi i drogi, dlatego ten typ demokracji nadaje się na czasy pokoju, a nie kryzysu i bardzo szybkich zmian.

Drugim proponowanym modelem demokracji $z$ elementami demokracji bezpośredniej jest demokracja deliberatywna wprowadzająca swobodną dys-

${ }^{7}$ Autorka uczestniczyła w spotkaniach przedstawicieli szwajcarskich instytucji publicznych, na których przedstawiano model szwajcarski i zachęcano do podobnych rozwiązań. 
kusję nad problemami, co ma służyć wypracowywaniu rozwiązań kompromisowych (Sartori 1998). Chodzi zatem nie tylko o tworzenie najbardziej demokratycznych procedur wyborczych, ale o przekształcanie preferencji obywateli przez otwartą debatę.

Innym pomysłem jest demokracja, której nazwa jest tautologią: demokracja partycypacyjna. Polega na uczestnictwie obywateli nie tylko $\mathrm{w}$ głosowaniach referendalnych nad ustawami, ale na ich zbiorowym tworzeniu. A dziś takie możliwości istnieją. Płaszczyzną do wspólnego pisania dokumentów może być internet. Najnowszym zastosowaniem tego rozwiązania był pomysł napisania nowej konstytucji Islandii przez internetowy crowd-sourcing. Zmiana konstytucji miała uzdrowić atmosferę w kraju po krachu bankowym i odbudować zaufanie do polityków. Sam proces obrósł już w legendę, doczekał się wielu entuzjastycznych omówień w prasie światowej. Światowe media, w tym polskie ${ }^{8}$, okrzyknęly islandzki przypadek uchwalania konstytucji jako wzór dla innych społeczeństw. Warto mu się przyjrzeć nieco dokładnej.

Tworzenie nowej konstytucji miało przebiegać w trzech fazach. Najpierw narodowe forum złożone $z$ tysiąca obywateli wybranych losowo jako próba reprezentatywna miało opracować zasady i wartości, na których miała się opierać nowa konstytucja. Później komitet konstytucyjny, złożony z siedmiu nominowanych przez partie osób, miał zebrać i przeanalizować idee dyskutowane na narodowym forum oraz zaproponować kierunki zmian. Następnie konstytuanta obywatelska, złożona z 25 osób wybranych przez obywateli, na podstawie prac narodowego forum i komitetu konstytucyjnego miała dokonać rewizji starej konstytucji.

Do obywatelskiej konstytuanty na 25 miejsc startowało 522 kandydatów, co świadczyło o dużym zainteresowaniu tematem - pomysł spełniał dwa postulaty demokracji: partycypacji i edukacji obywatelskiej. Wybory z powodów technicznych zostały unieważnione - wzięło $\mathrm{w}$ nich udział zaledwie $37 \%$ uprawnionych do głosowania - ale parlament, na podstawie przysługującego mu prawa, powołał komisję złożoną z osób wybranych do obywatelskiej konstytuanty (Bergmann 2014, s. 175-183). Komisja sporządziła 700-stronicowy raport $z$ działalności komitetu konstytucyjnego i narodowego forum, następnie zaproszono Islandczyków do dyskusji nad zgłoszonymi propozycjami. Odbywała się ona na spotkaniach otwartych i przez media społecznościowe: przez FB i Twittera. W kolejnych tygodniach komisja zamieszczała $w$ internecie propozycje kolejnych artykułów do przeczytania przez publiczność. Po uwzględnieniu uwag ekspertów i obywateli zamieszczała na stronie nową, zrewidowaną wersję. W ten sposób stopniowo, w kolejnych odsłonach powstawał cały dokument. Uwag i sugestii było jednak tak dużo (16 tysięcy), że mimo licznego

8 Zob. np. Morris 2012 czy w „Gazecie Wyborczej” w 2012 roku: Islandia pyta obywateli, co wpisać do konstytucji. Precedensowe referendum lub Islandia. Referendum: dwie trzecie za nowa konstytucją. 
personelu komisja nie była w stanie odnieść się do wszystkich, tak że niektórzy obywatele mogli czuć się z tego powodu nieusatysfakcjonowani (Bergmann 2014).

W następnym roku projekt przeszedł do komisji parlamentarnych, które doprecyzowały prawnie tekst, i w październiku 2012 roku został on ostatecznie poddany ogólnonarodowemu referendum. Dwie trzecie głosujących było za projektem jako bazą dla prac komisji konstytucyjnej parlamentu. Zgromadzenie Narodowe, mając pół roku do końca kadencji, przesunęło uchwalenie konstytucji na po wyborach w 2013 roku. Nowy parlament powołał nową komisję, ale nie ma ona woli, by wprowadzić nową konstytucję. Do września 2015 roku nowa ustawa zasadnicza nie została przyjęta.

Pomysł pisania konstytucji przez crowd-sourcing podzielił islandzką scenę polityczną. Jedne ugrupowania wierzyły, że to sposób na odbudowanie zaufania obywateli, inne, że to zamach na tradycję. Zdecydowanie przeciwni projektowi byli prawnicy, uważający, że tak ważnego dokumentu nie powinni pisać amatorzy. Krytycznie do pomysłu islandzkiego odniósł się również Iwan Krastew. W Demokracji nieufnych powątpiewał w sukces crowd-sourcingu ustawodawczego (2013, s. 36), przestrzegając jednocześnie przed przesadną transparentnością procesu decyzyjnego jako metodą przywrócenia zaufania do demokracji. Inaczej zareagował czołowy badacz ruchów społecznych i społeczeństwa informacyjnego Manuel Castells, wypowiadając się z entuzjazmem o islandzkim pomyśle: „Fakt, że konstytucja jakiegoś kraju może obejmować zasady rewolucyjne w kontekście globalnego kapitalizmu, ukazuje bezpośredni związek między procesem autentycznie powszechnego crowd-sourcingu a treścią stworzoną w tak demokratyczny sposób" (Castells 2013, s. 54). Jego zdaniem, ten model uczestnictwa można zastosować do większych społeczeństw: „Nowa konstytucja islandzka może stać się inspiracją dla demokracji XXI wieku, jak konstytucja Korsyki [napisana przez Rousseau M.B.B.] dla proklamowania wolności w Stanach Zjednoczonych" (Castells 2013, s. 56).

Przejdźmy teraz do drugiego tematu podjętego przez Krastewa, dotyczącego ruchu oburzonych. Czy odpowiedzią na kryzys demokracji postpolitycznej może być inny sposób realizacji demokracji, nie przez referenda i wybory, lecz przez wyjście na ulice? Czy masowe protesty, jakie odbywały się w drugiej dekadzie XXI wieku w wielu miastach na świecie, wyznaczają zmianę sposobu praktykowania polityki? A może to tylko widowiskowa, lecz w gruncie rzeczy nieistotna erupcja publicznego gniewu? - pyta Krastew w drugim eseju pt. Demokracja: przepraszamy za usterki. I od razu odpowiada: protesty nie są alternatywą dla wyborów i „tradycyjnego" uprawiania polityki, ponieważ niczego nie proponują, nie wprowadzają żadnego projektu ani nowego programu. Więcej protestujący nie tylko nie mają wspólnego projektu, ale głoszą hasła sprzeczne, bo wyrażają niezgodę na nierówności, ale również niezgodę na redystrybucję bogactwa; chcą ograniczenia roli państwa, ale jednocześnie żądają poprawy ja- 
kości usług publicznych ${ }^{9}$. Protesty nie rozwiązują żadnych problemów i nie są sensowym sposobem rządzenia i decydowania, nie kształtują alternatywnej elity, bo z założenia są antyliderskie i antyprzywódcze. Protesty nie przywróciły zaufania do instytucji publicznych, raczej - jak przekonuje Krastwe (2015, s. 17) - „zamieniły nieufność do instytucjonalnych norm w samą normę". Mimo tych zastrzeżeń uważa, że protesty były jednak czymś jakościowo nowym - pokazały rządzącym granice ich władzy, w tym sensie nadają się do kontroli rządzących. „Protesty przypominają ludziom władzy o granicach, do jakich elita może zawłaszczyć demokratyczne instytucje” (2015, s. 80).

Protesty były wybuchami moralnego oburzenia na sposób sprawowania władzy, ale nie chodziło w nich o zmianę elity — uczestnicy ruchu nie byli zainteresowani przejęciem władzy, w tym sensie nie byli rewolucją antykapitalistyczną. Chodziło w nich o zmianę sposobu działania władzy, dlatego Krastew nazywa ten typ protestu średniowiecznym. W średniowieczu buntujący się lud na ogół nie domagał się obalenia króla, tylko dostrzeżenia przez króla losu poddanych i innego zarządzania królestwem.

To, co zdecydowanie nowe w obecnych ruchach, to sposób ich zorganizowania i mobilizacji — przez sieć. Można powiedzieć, że sam ruch jest siecią: „Nowe ruchy społeczne, traktujące same siebie jako sieci, przekonały się, że sieci mogą pokonać hierarchię. Wszechpotężna sieć to organizacyjna broń z wyboru, tak samo jak mała, lecz zdyscyplinowana partia rewolucyjna była organizacyjną bronią wybraną przez komunistów" (2015, s. 24). Krastew, inaczej jednak niż Castells, który bezimienne nowe ruchy protestu u progu XXI wieku określił jako „sieci oburzenia i nadziei”, nie zachwyca się samoorganizacją sieciową i mobilizacją przez media społecznościowe, ponieważ przeceniają one możliwości protestujących, stwarzając pozory ich siły i ogromnej popularności. Media społecznościowe ujawniają wprawdzie frustrację protestujących, ale poparcie, które pokazują, na ogól jest przeskalowane. To pozorny „efekt większości", tworzący złudzenie, że każdy, kto napisał w sieci coś pozytywnego o protestach, jest po stronie protestujących.

Najciekawsza część analizy Krastewa związana jest z zastosowaniem do protestów oburzonych rozróżnienia amerykańskiego ekonomisty Alfreda Hirschmana. Pisząc o niezgodzie na status quo wymienia on dwie strategie: pierwszą — rozstania, odmowy, której rezultatem może być zaniechanie walki o zmianę; najczęściej jej urzeczywistnieniem jest wyjazd, emigracja. I drugą — krytyki, która przejawia się $\mathrm{w}$ pokojowym żądaniu reform lub $\mathrm{w}$ protestach mających wymusić zmiany. Te dwie, wydawałoby się, rozłączne reakcje na status quo czasami mogą się spotkać. Wprawdzie emigracja jest rozstaniem i nie oddziałuje

${ }^{9}$ Ale czy niekoherencja ruchu jest aż tak bardzo nietypowa? W całej myśli liberalnej jest pęknięcie i to od momentu powstania, bo z jednej strony liberalizm żądał ograniczenia ingerencji rządu i państwa, z drugiej wymagał, by państwo, w imię wolności jednostki i jej prawa do rozwoju, stworzyło jej do takiego rozwoju warunki, a to oznaczało wzmocnienie roli państwa. 
na zmiany, ale zbyt duża emigracja może doprowadzić do radykalnych przemian (Niemcy po fali emigracji z NRD w 1989 roku). Protesty to generalnie krytyka, ale $\mathrm{w}$ protestach może chodzić o odmowę udziału w systemie. Zdaniem Krastewa współczesne protesty mają więcej z opcji wyjścia niż krytyki. Oburzeni wychodzą na scenę, by odrzucić to, co jest, a nie reformować. Jest to demokracja odmowy i rozstania (2015, s. 67).

Czy jednak rzeczywiście protesty oburzonych są nowym zjawiskiem, poza skalą i nowym sposobem mobilizacji i zorganizowania? Gdyby przywołać klasyczną definicję ruchu społecznego sformułowaną przez Jana Pakulskiego (1988), to ruchy oburzonych spełniałyby wszystkie wymienione przez niego cechy. Były antysystemowe, antyinstytucjonalne, antyrynkowe, antyrządowe, antypartyjne, bardziej „przeciw” niż „za”, brakowało w nich wspólnej platformy zmian. Niektóre hasła były konkretne, ale inne abstrakcyjne, w wielu momentach chodziło raczej o "ducha moralnej krucjaty”. Ruchy społeczne na ogół nie mają przywódców i struktur formalnych, ochotnicy działają przez zrywy, legalnymi lub quasi-legalnymi, ale niecodziennymi metodami. W tym sensie oburzeni to dość typowy nowoczesny ruch społeczny, odmienny od wcześniejszych, bo bardzo liczny i stosujący inne narzędzia mobilizacji, choć - jak przyznawał w debacie Tischnerowskiej sam Krastew - zwykle przecenia się rolę nowych mediów i umniejsza rolę tradycyjnej telewizji, wciąż odgrywającej decydującą funkcję na dalszych etapach protestu ${ }^{10}$.

Klasyczny podział polega na wyodrębnieniu tzw. starych i nowych ruchów społecznych. „Stare” to te o podłożu ekonomiczno-społecznym, domagające się rozwiązania konkretnych problemów; „nowe” - kulturowe, odnoszą się do stylów życia, obyczajowości, jak to miało miejsce w latach sześćdziesiątych i siedemdziesiątych XX wieku w przypadku ruchu hipisowskiego, Ery Wodnika, pacyfistycznego czy ruchu Zielonych. Ruch oburzonych łączy cechy „starych" i „nowych” ruchów społecznych, bo dotyczy podłoża ekonomiczno-społecznego, zgłasza żądania rozwiązania bardzo konkretnych problemów, ale ma „nowe” formy działania: jest nieustrukturyzowany, bez przywódców i ideologii, bez projektu, narzędziem mobilizacji są media społecznościowe. Różnica w stosunku do wcześniejszego ogólnoświatowego ruchu alterglobalistów jest taka, że ci ostatni domagają się rozwiązania problemów globalnych (oddłużenia krajów Trzeciego Świata i innej ekonomii międzynarodowej) oraz dość konkretnych (wprowadzenia podatku Tobina, zmiany polityki w badaniach farmaceutycznych, ograniczenia agricultural factory i ochrony puszczy amazońskiej).

\footnotetext{
10 Krastew, odwołując się do Hirschmana, mówi o zbiorowych cyklach zaangażowania, oscylacjach aktywności między okresami intensywnego zajmowania się sprawami publicznymi a niemal absolutnym brakiem zainteresowania i skupieniem się na sprawach prywatnych. Ale nie jest to chyba specjalnie oryginalna obserwacja, gdyż badacze ruchów społecznych od dawna wskazywali na erupcję w tym samym czasie różnego rodzaju ruchów społecznych. Można mówić o dyfuzji nastrojów sprzyjających ruchom społecznym, po których zwykle następuje okres pasywny.
} 
Oburzeni zgłaszają własne problemy w ramach swojego kraju, i w tym sensie są bardziej „starym” niż „nowym” ruchem społecznym.

Ruchy społeczne zwykle są opisywane i badane pod trzema względami: zmiany społecznej - w jakim stopniu przyczyniają się do ewolucji systemu; mobilizacji społecznej — jak aktywizują sympatyków ruchu i jak organizują ruch; oraz wytworzenia wspólnoty, co Krastew określił jako „sposób bycia w świecie, a co niektórzy badacze nazywają, odwołując się do wspólnoty wojskowej, esprit de corps - dzięki jakim elementom i rytuałom tworzą wspólnotę. Ruch oburzonych był opisywany w tych trzech aspektach, choć jak się wydaje dziś, po kilku latach od protestów, jego oddziaływanie na zmianę społeczną okazało się niewielkie. Odniósł ogromny sukces, jeśli chodzi o mobilizację, ale duch wspólnoty wyparował całkowicie.

Może jednak protesty oburzonych były wynikiem nie, jak chce Krastew, braku zaufania do państwa, ale poczucia gniewu z powodu zranionej dumy, że obywateli się nie zauważa. Protesty były wyrazem postawy tymotejskiej, jak określił ten typ działania Peter Sloterdijk (2011). Protest w postaci ruchu oburzonych skupił indywidualny, rozproszony gniew, by z niego wytworzyć coś wspólnego. Sloterdijk na opisanie protestu gniewnych jednostek używa metafory banku. Rozproszony gniew indywidualny jest jak skarb, który wprawdzie jest, ale którego nie przybywa; protest zbiorowy kumulujący indywidualne gniewy jest jak depozyt kapitałowy, którym się zarządza i którego wartość rośnie. „Rozumiemy przez to — pisze Sloterdijk (2011, s. 73) — przejęcie lokalnych zasobów złości i rozsianych projektów nienawiści przez pewną instancję o szerszym zasięgu, której zadanie, jak w każdym autentycznym banku, polega na pełnieniu roli punktu zbiorczego i agencji realizacji. Przejście to wpływa nieuchronnie na strukturę temporalną uwikłanych w pojedyncze projekty potencjałów. Tak jak zemsta jako gniew w formie projektu rozciąga go w czasie i pozwala dojrzewać pragmatycznemu planowaniu, tak gniew $\mathrm{w}$ formie banku wymaga od pojedynczych mścicielskich impulsów włączania się w pewną nadrzędną perspektywę. [...] Wraz ze wzrostem rangi organizacji gniewu dokonuje się racjonalizacja mścicielskich energii: przebiega ona od czystej impulsywności poprzez punktowe uderzenie aż do koncepcji zamachu na globalny ład". Zatem jaki jest projekt na dziś: „Obudzić thymós oburzonych”, mówi Sloterdijk (2011, s. 129). I ta perspektywa być może lepiej opisuje oburzonych niż nieufność, bo protesty nie odbudowały zaufania do instytucji społecznych, ale przypomniały o godności protestujących.

„U początków liberalnej polityki i ekonomii stoi nieufność” — pisze Russell Hardin w książce Zaufanie (2009, s. 144). W ekonomii widać ją już u Adama Smitha w jego słynnym zdaniu: „Nie od przychylności rzeźnika, piekarza i piwowara powinniśmy oczekiwać naszego obiadu, ale od ich dbałości o własny 
interes". Tę dbałość o własny interes i związany z nią brak zaufania do władzy widać w myśli amerykańskiej, w tzw. filadelfijskiej klauzuli handlowej. Ograniczała ona prawa rządu do ingerowania w sprawy handlowe poszczególnych stanów, ponieważ nie ufano władzy centralnej, pamiętając politykę angielską wobec Ameryki (Hardin 2009, s. 150-153). Klauzula, obok konstytucji i Karty Praw, stała się dokumentem założycielskim Stanów, czyli można powiedzieć, że jeden $z$ aktów fundacyjnych Stanów Zjednoczonych powstał jako wyraz nieufności wobec rządu.

W Europie zasada nieufności wobec rządzących występuje już u Monteskiusza $\mathrm{w}$ jego propozycji ograniczenia władzy przez jej podział i wzajemną kontrolę. Chyba najlepiej ten rodzaj nieufności wobec rządzących wyraził David Hume (1955, s. 42) mówiąc, że w sferze polityki trzeba stworzyć takie instytucje, które działałyby nawet wtedy, gdy zostaną wybrani niegodziwcy.

Iwan Krastew nie zajmuje się nieufnością liberalną, związaną z zabezpieczeniem indywidualnej wolności i praw, ale nieufnością demokratyczną. Nieufnością do demokracji jako sposobu sprawowania władzy, który generuje brak zaufania do instytucji publicznych i samych polityków (proces odwrotny jest dość oczywisty: brak zaufania do konkretnych polityków przekłada się na brak zaufania do instytucji demokratycznych, a ten na nieufność do całego systemu). W tym stanie demokracja doszła do ściany, nie jest zdolna do autokorekty. Rozwiązania, które się proponuje: więcej wyborów, więcej demokracji bezpośredniej, więcej transparentności, nie są adekwatne do sytuacji, nie likwidują braku zaufania. A problem zaufania $\mathrm{w}$ demokracji jest ważniejszy niż $\mathrm{w}$ innych systemach, bo zagraża jej istocie. Jeżeli w demokracji, która z definicji ma charakter proceduralny, proces alokacji władzy w instytucjach państwowych podlega modyfikacji za pomocą działań pozaproceduralnych, to nie ma żadnego powodu, dla którego obywatele mieliby respektować formalne reguły delegowania władzy na rządzących. Korupcja, niejasne powiązania, naciski grup oligarchicznych, sprzyjanie interesom elit finansowych prowadzą do całkowitej delegitymizacji systemu, bo podważają jego fundament.

Demokrację należy przemyśleć na nowo. Poza wymienionymi przez Krastewa problemami trzeba wziąć pod uwagę jeszcze inne kwestie: nowe określenie suwerena - czyli podmiotu demokracji, szczególne prawa dla grup mniejszościowych (w sensie socjologicznym), władzę i autonomię regionów, poziom udziału demokracji bezpośredniej w przedstawicielskiej. Jeśli chodzi o to ostatnie, to z pewnością występuje oczekiwanie na więcej demokracji bezpośredniej w partyjnej demokracji przedstawicielskiej. Takim symbolem oczekiwań było krótkotrwałe poparcie dla JOW-ów w Polsce, choć wiadomo, że zmieniają one jedynie sposób wybierania reprezentantów (odpartyjniaja), ale nie zbliżają do demokracji bezpośredniej (poza innymi wieloma wadami, jakie wprowadzaja). Innym pomysłem są budżety partycypacyjne w miastach, zdobyły one uznanie i autentycznie obudziły obywatelskie zaangażowanie. 


\section{BIBLIOGRAFIA}

Bergmann Eirikur, 2014, Reconstituting Iceland - and the New Critical Order, w: Eirikur Bergmann, Iceland and the International Financial Crisis: Boom, Bust, Recovery, Palgrave Macmillan, Hampshire, NY.

Castells Manuel, 2013, Sieci oburzenia i nadziei. Ruchy spoleczne $w$ erze internetu, thum. Olga Siara, Wydawnictwo Naukowe PWN, Warszawa.

Chang Ha-Joon, 2015, Ekonomia. Instrukcja obstugi, tłum. Barbara Szelewa, Wydawnictwo Krytyki Politycznej, Warszawa.

Hardin Russell, 2009, Zaufanie, tłum. Agnieszka Gruba, Sic!, Warszawa.

Heywood Andrew, 2010, Polityka i sposoby jej definiowania, w: Andrew Heywood, Politologia, tłum. różni, Wydawnictwo Naukowe PWN, Warszawa.

Hume David, 1955, Eseje z dziedziny moralności i literatury, tłum. Teresa Tatarkiewicz, Wydawnictwo Naukowe PWN, Warszawa.

Islandia pyta, 2012, Islandia pyta obywateli, co wpisać do konstytucji. Precedensowe referendum, „Gazeta Wyborcza", 20 października.

Islandia, 2012, Islandia. Referendum: dwie trzecie za nową konstytucja, „Gazeta Wyborcza”, 21 października.

Krastew Iwan, 2013, Demokracja nieufnych, tłum. Michał Sutowski, Wydawnictwo Krytyki Politycznej, Warszawa.

Krastew Iwan, 2015, Demokracja: przepraszamy za usterki, tłum. Michał Sutowski, Wydawnictwo Krytyki Politycznej, Warszawa.

Kymlicka Will, 1989, Liberalism, Community and Culture, Clarendon Press, Oxford.

Kymlicka Will, 1995, Multicultural Citizenship: A Liberal Theory of Minority Rights, Clarendon Press, Oxford.

Lesińska Magdalena, 2013, Inkluzja polityczna imigrantów we wspótczesnej Europie, Scholar, Warszawa.

Madison James, Federalist Papers, 63 paragraf 14.

Marshall T.H., 1950, Citizenship and Social Class and Other Essays, Cambridge University Press, Cambridge.

Morris Harvey, 2012, Crowdsourcing Iceland's Constitution, „International Herald Tribune”, nr 10.

Modood Tariq, 2014, Multikulturalizm, tłum. Izabela Kołbon, Wydawnictwo Nauka i Innowacje, Poznań.

Monteskiusz, 1997, O duchu praw, tłum. Tadeusz Boy-Żeleński, Antyk, Kęty.

Pakulski Jan, 1988, Social Movements in Comparative Perspective, „Research in Social Movements, Conflicts and Change", t. 10, s. 247-267.

Quinn Frederick, 1999, Eseje polityczne federalistów, tłum. Barbara Czarska, Znak, Kraków.

Sartori Giovanni, 1998, Teoria demokracji, tłum. Piotr Amsterdamski, Daniel Grynberg, Wydawnictwo Naukowe PWN, Warszawa.

Schumpeter Joseph, 2009, Kapitalizm, socjalizm, demokracja, tłum. Michał Rusiński, Wydawnictwo Naukowe PWN, Warszawa.

Sloterdijk Peter, 2011, Gniew i czas. Esej polityczno-psychologiczny, tłum. Arkadiusz Żychliński, Scholar, Warszawa.

Taylor Charles, 1992, Multiculturalism and „The politics of recognition”: An Essay, w: Amy Gutmann, Multiculturalism and „The politics of recognition”: An Essay, Princeton University Press, Princeton.

Tilly Charles, 2008, Demokracja, tłum. Michał Szczubiałka, Wydawnictwo Naukowe PWN, Warszawa.

Young Iris, 2000, Inclusion and Democracy, Oxford University Press, Oxford. 


\section{THE POST-POLITICAL DEMOCRACY OF THE DISTRUSTFUL: COMMENTARY ON ESSAYS BY IVAN KRASTEV}

\section{Summary}

In his essays, collected in In Mistrust We Trust: Can Democracy Survive When We Don't Trust Our Leaders? and Democracy Disrupted: The Politics of Global Protest, Ivan Krastev questions the state of contemporary democracy. He describes it as 'post-political' because while procedures are observed, democratic elections take place, and governments are sometimes replaced, nothing of substance changes in politics and voters lack any sense of having influence or that their votes actually matter. Democracy is obviously in crisis, and a variety of solutions to this predicament have been proposed: even more elections, more direct democracy, or more transparency. Or perhaps a remedy to the crisis of democracy will stem from protests and from 'taking to the streets'-these being 'alternate means' of doing politics? Krastev criticizes all the above proposals, concluding that none is satisfactory or likely to restore trust in democratic institutions. Perhaps democracy ought not to be superficially improved, but instead rethought from the beginning? The author points to several questions that should be taken into account in thinking about a new form of democracy. She also considers whether the mass protests of the 2010s were a new phenomenon and involved new ideas for doing politics, or were typical modern social movements, only on a global scale and employing novel instruments of mobilization.

\section{Key words/słowa kluczowe}

democracy / demokracja; direct democracy / demokracja bezpośrednia; crowd-sourcing the constitution / crowd-sourcing konstytucji; crisis of democracy / kryzys demokracji; Indignants movement / oburzeni; social movements / ruchy społeczne 